\title{
Paleontology and depositional environments of the Tatuí and Irati formations (Permian) in the Ponte Nova Farm, Ipeúna, state of São Paulo
}

\author{
Artur Chahud', Mírian Liza Alves Forancelli Pachecoํ, Felipe van Enck Meira', \\ Guilherme Raffaeli Romero ${ }^{1}$ \& Setembrino Petri $^{2}$
}

\begin{abstract}
The Paraná Basin, located at the center-eastern South America, exhibits a thick succession of Late Paleozoic deposits. Two early Permian formations are present in the State of São Paulo, Brazil: Tatuí (the oldest) and Irati. Two members make up the Irati Formation - the Taquaral (the oldest) and Assistência. This paper discusses the facies of the upper Tatuí Formation and Taquaral Member, and their fossil content, mainly at the Ponte Nova Farm. This locality exhibits well-preserved outcrops of both units, with informative data on the facies relationships and their fossils. Crustaceans and vertebrates are presented at both the Tatuí and Taquaral beds. Different facies were recognized at Ponte Nova Farm, based on lithosomes, fossils and their relationships. In this context, a complex six facies architecture displayed at this locality allowed the formulation of a paleoenvironment hypothesis for the generation of the Tatuí Formation. The fine cross-bedded sandstone with subordinate planeparallel strata (facies 1) might have been laid down by a rather topographic mild coastal environment. Facies 2 is the result of low energy slack water subenvironment passing to facies 3, a high energy water system. The facies 4 is the result of an encroaching coastal environment over the continent. Taquaral facies 5 might be the result of a very high energy, body of water, becoming very quieter later, when facies 6 was deposited.
\end{abstract}

Keywords: Stratigraphy, Taphonomy, Paraná Basin, Crustaceans, Vertebrates, Brazil.

\begin{abstract}
Resumo Paleontologia e ambientes deposicionais das formações Tatuí e Irati (Permiano) na Fazenda Ponte Nova, Ipeúna, Estado de São Paulo. A Bacia do Paraná, localizada no centro-leste da América do Sul, apresenta espessa sucessão de depósitos neopaleozoicos. Três formações permianas estão presentes no Estado de São Paulo, Brasil: Tatuí (mais antiga) e Irati. Dois membros compõem a Formação Irati - o Taquaral (o mais antigo) e Assistência. Este artigo discute a fácies superior da Formação Tatuí e o Membro Taquaral, seu conteúdo fossilífero, principalmente na Fazenda Ponte Nova. Esta localidade exibe afloramentos bem preservados de ambas as unidades, com dados informativos sobre as relações de fácies e seus fósseis. Crustáceos e vertebrados são apresentados em ambos os leitos de ambas as unidades, Tatuí e Taquaral. Diferentes fácies foram reconhecidas na Fazenda Ponte Nova, com base em litossomas, fósseis e suas relações. Neste contexto, a complexa arquitetura de seis fácies evidenciadas nesta localidade permitiu a formulação de uma hipótese para a geração paleoambiental da Formação Tatuí. O arenito fino de estratificação cruzada com estratos plano-paralelos subordinados (fácies 1) poderia ter sido depositado em ambiente costeiro de baixo relevo. O subambiente depoiscional da fácies 2 foi de aguas de baixa corrente passando para a fácies 3, um sistema de alta energia. A fácies 4 é o resultado do avanço da linha de costa. A fácies 5, basal do Membro Taquaral, poderia ser o resultado de alta energia gerada por ondas, tornando-se muito mais calma acima gerando os depósitos da fácies 6.
\end{abstract}

Palavras-chave: Estratigrafia, Tafonomia, Bacia do Paraná, Crustáceos, Vertebrados, Brasil.

\begin{abstract}
INTRODUCTION The knowledge on the Tatuí Formation paleontology is scarce, being restricted to descriptions of crustaceans and bibliographic citations on plants and microfossils (crustraceans, acritarchs and agglutinating foraminifera) (Fúlfaro et al. 1984, Cabral Jr. et al. 1988, Mezzalira \& Martins Neto 1992). As for Taquaral Member paleontology, detailed research has been done (Mezzalira 1952, Chahud 2007, Chahud \& Petri 2008a, b, 2010a, b, Chahud et al. 2010).
\end{abstract}

The Ponte Nova Farm is located at Ipeúna municipality area, on the margin of the Cateto stream, a small tributary of the Passa Cinco River. This location displays a sequence of various fossil-bearing levels of the Tatuí Formation, as well as sediments from the lower portion of the overlying Taquaral Member.

The central-east region of the São Paulo State exposes almost the entire Late Paleozoic-Mesozoic section of the northeast margin of Paraná Basin, starting with the Late Paleozoic sequences of the Tubarão Group

1 - Programa de Pós-graduação em Geoquímica e Geotectônica, Instituto de Geociências, Universidade de São Paulo, São Paulo (SP), Brasil.E-mail: arturchahud@yahoo.com, forancelli@gmail.com, fvemeira@gmail.com,graffaeli@gmail.com

2 - Departamento de Geologia Sedimentar e Ambiental, Instituto de Geociências, Universidade de São Paulo, São Paulo (SP), Brasil. E-mail: spetri@usp.br 
(Itararé Subgroup and Tatuí Formation) through the Passa Dois Group (Irati and Corumbataí formations) and ending with the Mesozoic São Bento Group (Piramboia, Botucatu and Serra Geral formations) (Milani et al. 2007).

The Tatuí Formation, restricted to the São Paulo State, is made up of successions of claystones and fine sandstones, being either locally massive or exhibiting hummocky cross stratification. Between these layers are conglomeratic levels of fluvial-deltaic origin (Stevaux et al. 1986, Assine et al. 2003). The formation is chronologically correlated to the Rio Bonito and Palermo formations in the south of Brazil, and to the Prince Albert Formation, in South Africa.

The Tatuí Formation is discordantly overlain by the Taquaral Member, the lowermost unit of the Irati Formation. It is composed, at the base, by conglomeratic sandstones containing remains of vertebrates, passing upward to non-bituminous parallel-bedding dark grey silty-clayey shales with dispersed pyrite crystals. This latter lithology characterizes most of the Taquaral Member.

The present study aimed the disclosure of the fossils found in this location and the stratigraphic relationships of the facies of the Tatuí and Irati formations. This paper also gives propositions about paleoenvironments of deposition of both formations, based on the studied records.

MATERIAL AND METHODS The material comes from outcrops of the Ponte Nova Farm (Fig. 1). The study area is well served by roads, mostly unpaved, with access through the highways SP-191, SP-310 and SP-330. All the material was registered and deposited in the "Laboratório de Paleontologia Sistemática" (LPS) of IGc/USP.

Digital images were obtained through an Omega Megascan $^{\odot}$ - ACCU 6000 Scanner and a SONY $3 \mathrm{CCD}^{\odot}$ analog camera, and processed by a LEICA $^{\odot}$ image analyzer in the Laboratório de Petrografia Sedimentar of the Geoscience Institute of the São Paulo University (IGc/USP). The softwares Corel Draw $12^{\circ}$ and MGI Photo Suite ${ }^{\odot}$ were used to deal with the images and the pictures. Analysis were made with a Zeiss $^{\odot}$ stereomicroscope, model SV6. Image capture was made with a digital camera $\mathrm{JVC}^{\odot}$ installed on the stereomicroscope, which transmitted the images to a PC microcomputer with the software AxioVision ${ }^{\odot}$.

These techniques were used for their high resolution power. Also, the software helped the achievement of the main fossil biometric parameters.

GEOLOGICAL SETTING OF PONTE NOVA FARM Ponte Nova Farm bears a sequence of Early
Permian rocks distributed in three outcrops, named here as points $\mathrm{A}, \mathrm{B}$ and $\mathrm{C}$. The distance from Point $\mathrm{A}$ to $\mathrm{B}$ is $120 \mathrm{~m}$, and $87 \mathrm{~m}$ from B to C. Topographic variation does not exceed $4 \mathrm{~m}$. Tatuí Formation is the predominant unit represented in the three points, with four distinct facies. At Point C, rocks from the Taquaral Member of the Irati Formation also outcrop composed by two facies: sandstone and silty shale (Fig. 2).

Facies 1 (Tatuí Formation): Characterized by a very fine well-sorted sandstone, light yellow color with tabular and tangential cross-beds, locally interbedded with parallel or slightly wavy laminae, specially close to the top the facies, where appear branchless tubular ichnofossils. At Point A the contact of the contact of facies 1 with the facies 2 is gradual, thinning upward to silt. At Point B the facies 2 is missing, therefore the contact between facies 1 and the overlying facies 3 is discordant (diastem).

Facies 2 (Tatuí Formation): this facies is basically composed of light yellow siltstone, with lesser sandy portions. Its thickness at Point $\mathrm{A}$ is about $2 \mathrm{~m}$, from which $1.21 \mathrm{~m}$ are interbedded, richly fossiliferous layers.

The commonest fossils are conchostraceans, usually found as accumulations, in addition to dispersed fragments of probable crustaceans. Ichtiofossils are rare. Though the vegetation around the outcrop area was high, it was possible to discern a sharp discordant contact (diastem) between facies 2 and 3 (Fig. 2).

At Point $\mathrm{C}$, this facies overlies facies 3 , with a whitish two-centimeter-thick microconglomerate bearing a few dark pebbles, close to the base. This layer has the same sedimentological features as the facies 3 conglomerates, which may correspond to a recurrent facies.

The total thickness of facies 2, at the Point C, is $56 \mathrm{~cm}$ (15 cm up to the conglomeratic layer). A conchostracean-bearing stratum within facies 2 was observed, but it was not possible to accurately situate it in the section.

Facies 3 (Tatuí Formation): a 1.5 m-thick sandy package, consisting of poor-sorted sandstone to conglomeratic sandstone. Clasts are mainly rounded, with a few angular ones, and do not exceed pebble dimensions.

At Point B, several centimeter-thick crossbedding stratifications are observed at distance. The beds, about $3 \mathrm{~m}$ thick, most of them are clast-matrix conglomerate, only chert clasts ranging between 1 to $10 \mathrm{~cm}$, rounded, only few elongated and, occasionally, angular.

It was not possible to accurately verify preferential currents in the analyzed structures, due to weathering. 


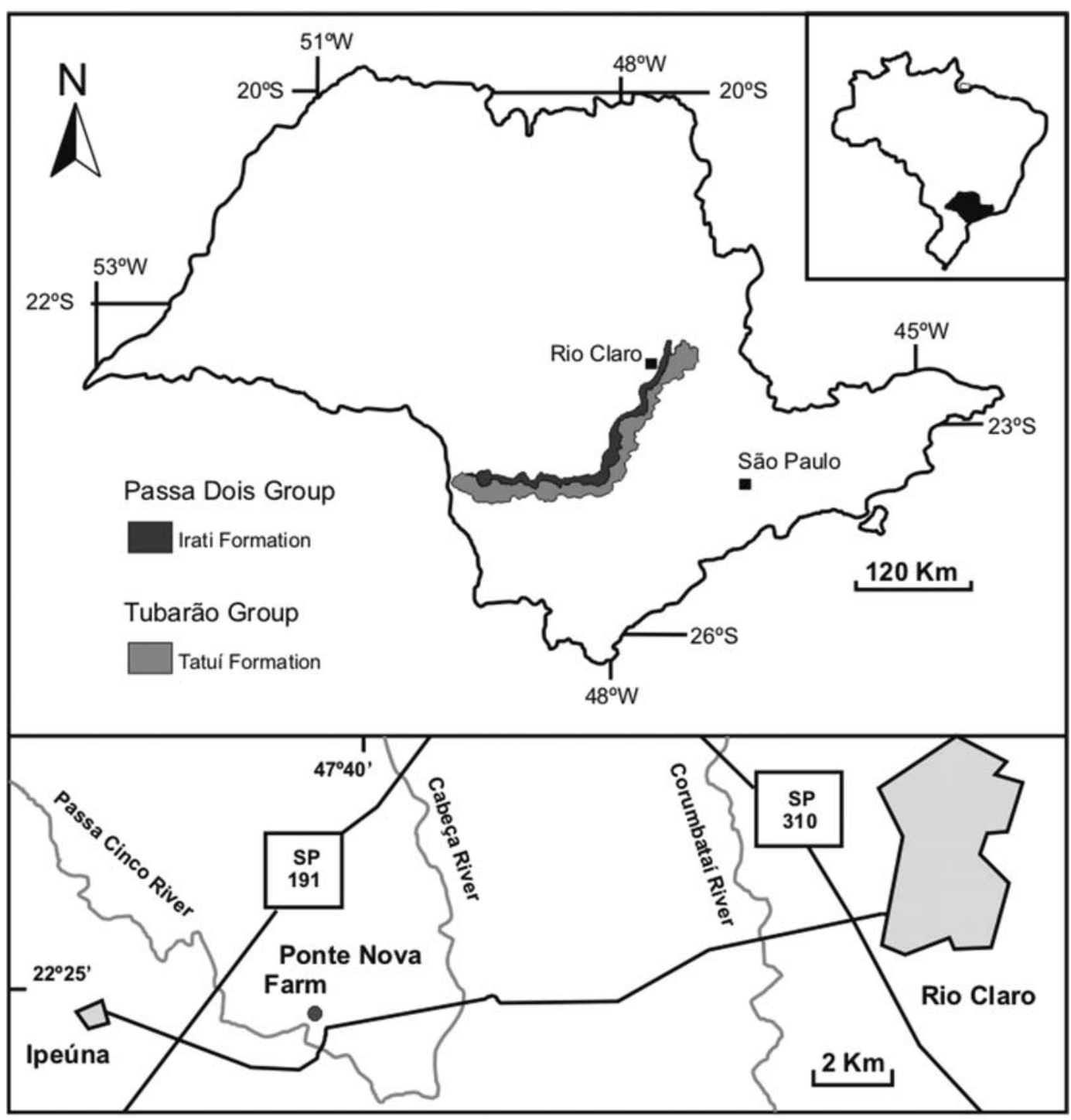

Figure 1 - Outcrop band of the Tatuí and Irati formations in the São Paulo State. A) region of Rio Claro and Ipeúna, showing the location of Ponte Nova Farm and access roads.

Facies 4 (Tatuí Formation): this facies, only observed at Point C, is characterized by well-sorted unweathered whitish fine sandstone. Most of them are massive, occasionally with cross-bedding stratifications.

It apparently represents a tabular slightly arched (dipping about 3-5 degrees), probably tectonic that affected the region after its deposition. It is about $60 \mathrm{~cm}$ thick. No fossils were found.

Facies 5 (Irati Formation): this facies, observed only at the Point C, represents the sandy base of the Taquaral Member (Chahud \& Petri 2008a, b, 2010a). Its average thickness is about $12 \mathrm{~cm}$. At Ponte Nova Farm, the facies consists of conglomeratic sandstone, with clasts ranging, from 1 to $10 \mathrm{~cm}$, with dispersed pyrite crystals. Some grey clayey beds within this facies herald the later paleoenvironments of deposition of facies 6 above. The facies 5 beds it contains abundant fish teeth and scales, similar to those observed by Chahud \& Petri (2008a, 2010b) and Chahud et al. (2010). The contact with the facies 4 is marked by an erosive discordance.

Facies 6 (Irati Formation): silty-clayey layer of the Taquaral Member, constituted by a homogeneous package of dark grey color, when unweathered. It is the largest outcrop exposed area, with $8 \mathrm{~m}$ thick. Parallelbedding stratification is horizontal and continuous through the facies. Most expositions are covered by present vegetation. The facies top exhibits sharp contact with diabases of the Serra Geral magmatism.

\section{GEOLOGICAL DISCUSSION ON PONTE NOVA}

FARM FACIES Points A, B and C can be considered as extensions of a single point, the former representing the lowest strata, and the third the top. The observed 
A

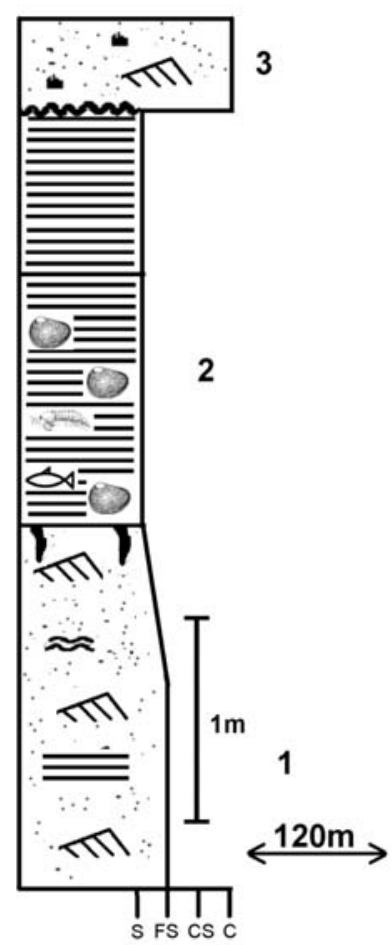

B

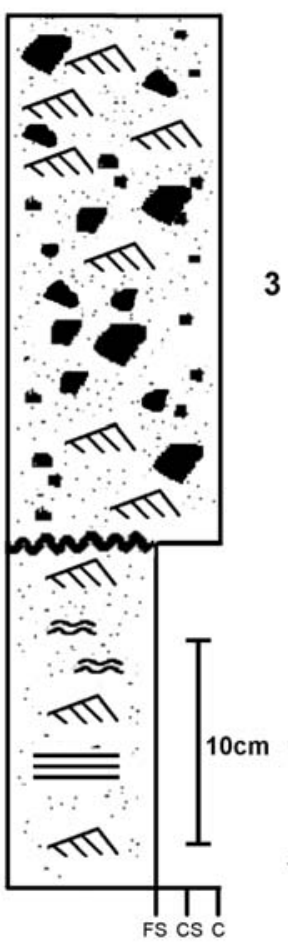

C

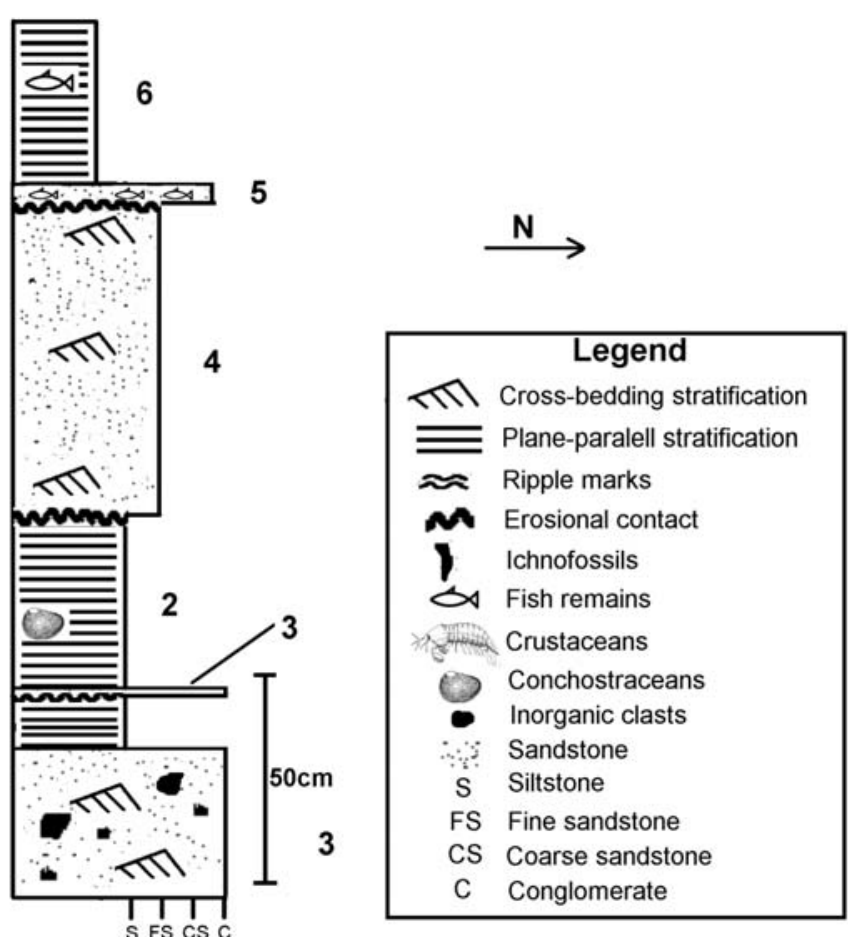

Figure 2 - Stratigraphic sections of the three points of the Ponte Nova Farm.

layers do not keep everywhere on stratigraphic succession. Therefore, the lithosomes 2 and 3 are considered as facies, displayed in an interbedded way at the Ponte Nova Farm.

Facies 1 is presented in points $\mathrm{A}$ and $\mathrm{B}$, keeping similarities of granulometry similarity and sedimentary structures, as wavy marks and crossbedding stratification. It was deposited in a coastal paleoenvironment of a water body, with some wave influence which gradually lacks energy, upward causing the evaporation of finer sediments.

Facies 2, observed at Point A (Fig. 2), was interpreted as laid down in quiet water, probably at pools.

The conglomeratic facies 3 , from the top of points $A$ and $B$ and base of the point $C$, is diagnostic of eventually deltaic downstream which, for its constitution and structure, originated the Ibicatu facies deposits (Soares 1972),. The deposition of this facies, in diastem on the facies 2 at Point $\mathrm{A}$, and over facies 1 at Point B, suggests that it was the result of a deposition often in overflow conditions in a fluvial channel. Perhaps due to lateral migration of the channel, the quiet slack water conditions returned, represented by the facies 2, above facies 3, at Point C (Fig. 2).

The sedimentary composition of facies 3 is typical of Ibicatu conglomerates first described by Soares (1972) between the cities of Leme and Araras,
$47 \mathrm{~km}$ northeastward Ponte Nova Farm. The facies is also similar in granulometry to the deposits of Limeira, Corrego do Veado outcrop (Stevaux et al.1986), as well as those located on the Rodovia do Açúcar, near the town of Rio das Pedras, about $50 \mathrm{~km}$ southward Ponte Nova Farm, described by Fúlfaro et al. (1984), Stevaux et al. (1986) and Assine et al. (2003). Soares (1972) described these strata to the top of Tatuí Formation, thought to be related to the sandy facies of Taquaral Member. Assine et al. (2003) and Chahud \& Petri (2010a) verified that these rocks are distinct from the Ibicatu layers, and therefore cannot be correlated with it.

Facies 2 and 3 would represent a strongly continental-influenced freshwater domain, probably correlated in age. The rainfall and climatic changes would have influenced the deposition of the coarse deposits. The increase of the energy in the rivers of the region would generate coarser sediments, in a short time, originating the Ibicatu conglomeratic deposits.

The facies 4 , at Point $C$, corresponds to the deposits of the top of Tatuí Formation, and would be related to the large sandy bodies with storm-generated structures found in the region (Chahud 2007, Chahud \& Petri 2008a, 2010a, Chahud et al. 2010). Though such structures were not seen in this study it was possible to sugest such an environment through similar to other places the granulometry. 
The uppermost two facies at the Point $\mathrm{C}$ are typical of Taquaral Member (Hachiro 1997, Chahud \& Petri 2008a, 2010a), the basal facies is sandy and bears fossil vertebrates, whereas the upper one facies 6 is constituted by grey silty shales. Facies 5 is the result of wave reworking caused by a rise in the water body later inducing the deposition of the silty sediments of facies 6 (Riccomini et al. 1997, Assine et al. 2003, Chahud 2007, Chahud \& Petri 2010a).

This silty-clayey shale facies of the Taquaral Member was recognized in much of the Paraná Basin by Hachiro $(1991,1997)$. It is the predominant unit of the Taquaral Member.

\section{PALEONTOLOGY OF PONTE NOVA FARM}

PHYLUM ARTHROPODA Latreille, 1829

SUPERCLASS CRUSTACEA Brünnich, 1772

CLASS BRANCHIOPODA Latreille, 1817

ORDER DIPLOSTRACA Gerstaecker, 1866 SUBORDER Indeterminate

Figures 3, 4, 5A and B

Material: accumulations and dispersed material. Location: Ponte Nova Farm, Ipeúna municipality, Point A.

Stratigraphy: facies 2 of Tatuí Formation.

Description: specimens are preserved as carapace impressions, with a few evident external morphological features. The umbo is easily observed in some cases. Growth lines are seldom observed, being difficult to individualize each one, this further prevented growth angle measurement on valves, in only some larger or more complete exemplars two or three growth lines could be seen at their margins, which helped in the discussion.

No detectable relief (convexity or concavity) was noted. In a few samples, complete conchostraceans impressions are visualized, displaying closed valves. Only a few individuals bear totally preserved valves, therefore constraining the sample number to biometrics analysis to 66 individuals. These exhibit a slightly oval morphology, with valve heights ranging from 0.98 to $3.54 \mathrm{~mm}$, and length from 1.25 to $5.57 \mathrm{~mm}$. Abundant fragmented specimens were also noted.

Discussion: Conchostraceans, a group embraced by Diplostraca, is defined as paraphyletic (Schminke 1981, Martin \& Clash-Clark 1995, Olesen et al. 1996, Olesen 1998). Conchostraceans are typical of non marine environments, adapted to restricted freshwater to oligohaline shallow water bodies, with less than one meter depth (Ferreira de Oliveira 2007). In this study, the best preserved individuals allowed the verification of oval valves (Figs. 3A-C), similar to conchostraceans assigned to the genera Cyzicus and Asmussia from the Rio do Rastro Formation (Brito et al. 2000, Ferreira de Oliveira 2007). More elongated exemplars, on the contrary, may be ascribed to the genus Euestheria. Some individuals present carapaces with straight edges, reminding possible Hemicycloleaia forms. Nevertheless, caution in taxonomic identification based on carapace morphology is needed. Most of taxonomic features rely on soft parts and appendices preservation, rarely preserved as fossils (Chen \& Hudson 1991). In addition, Kobayashi (1954) had already drawn the attention to polymorphism in conchostraceans. According to this author, polymorphism can be attributed to various factors, such as mutations, sexual dimorphism, ontogeny, and isolation of population.

The oldest citation refers to the Rio Bonito Formation, Permian of Paraná Basin, Bainha outcrop in Criciúma city, State of Santa Catarina (Bernardes de Oliveira 1977). Saad (1977) noted a conchostraceans -rich stratum in the Palermo Formation, close to the contact with Irati Formation, in the Paraná State. The stratigraphy in this paper was not well defined, but according to the geologic description, it is quite similar to the rocks ascribed to the Palermo Formation in southern Brazil. In the São Paulo State, the Tatuí Formation is coeval to the Rio Bonito and Palermo formations of the south.

Mezzalira \& Martins Neto (1992) described, without illustration, considered by them of the genus Cyzicus in an outcrop near Piracicaba city.

\section{TAPHONOMIC ANALYSIS OF CONCHOS-} TRACEANS The conchostraceans are always present in silty shale, in different position, in relation to other lithosomes at points A and C. Occur in interbedded strata, with many individuals forming localized accumulations. The concentration varies laterally and vertically in the section (Figs. 4A-D, 5A-B).

These fossils are very compacted and occasionally displayed as simple carapace impressions as an apparently monotypic assemblage.

They are either isolated carapaces or closed valves. Some specimens clearly show different degrees of valve dislocation (Figs. 3D-E). Associated to conchostraceans are fragments of crustacean or undetermined arthropods and Palaeonisciformes loose scales (Figs. 5E-F).

Time-averaging and/or spatial-averaging are also possible to have occurred, as different size individuals with different taphonomic signatures were noted.

According to the obtained data, we infer that the variation in conchostraceans concentration may reflect composition shifts in the water body from time to time. Such events may be related to subtle increase or 

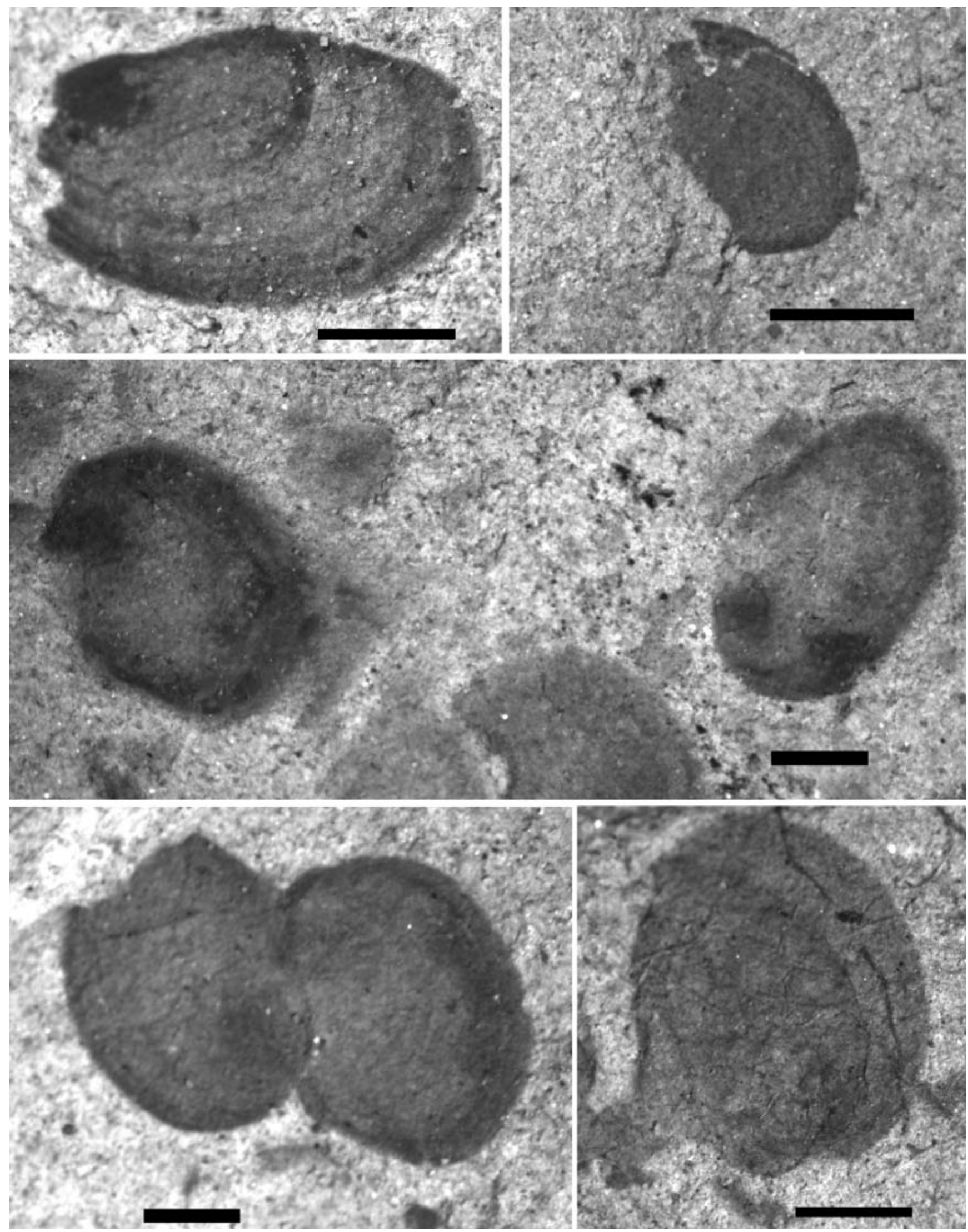

Figure 3 - Conchostraceans from Point A of Ponte Nova Farm. A and B) Conchostraceans showing incomplete carapace (A) GP/1E-6203; B) GP/1E-6197. C) Conchostraceans with possible organic remains, GP/1E-6201. D and E) Conchostraceans with disarticulated valves (D) GP/1E-6199; E) GP/1E-6200. Scale $1 \mathrm{~mm}$. 

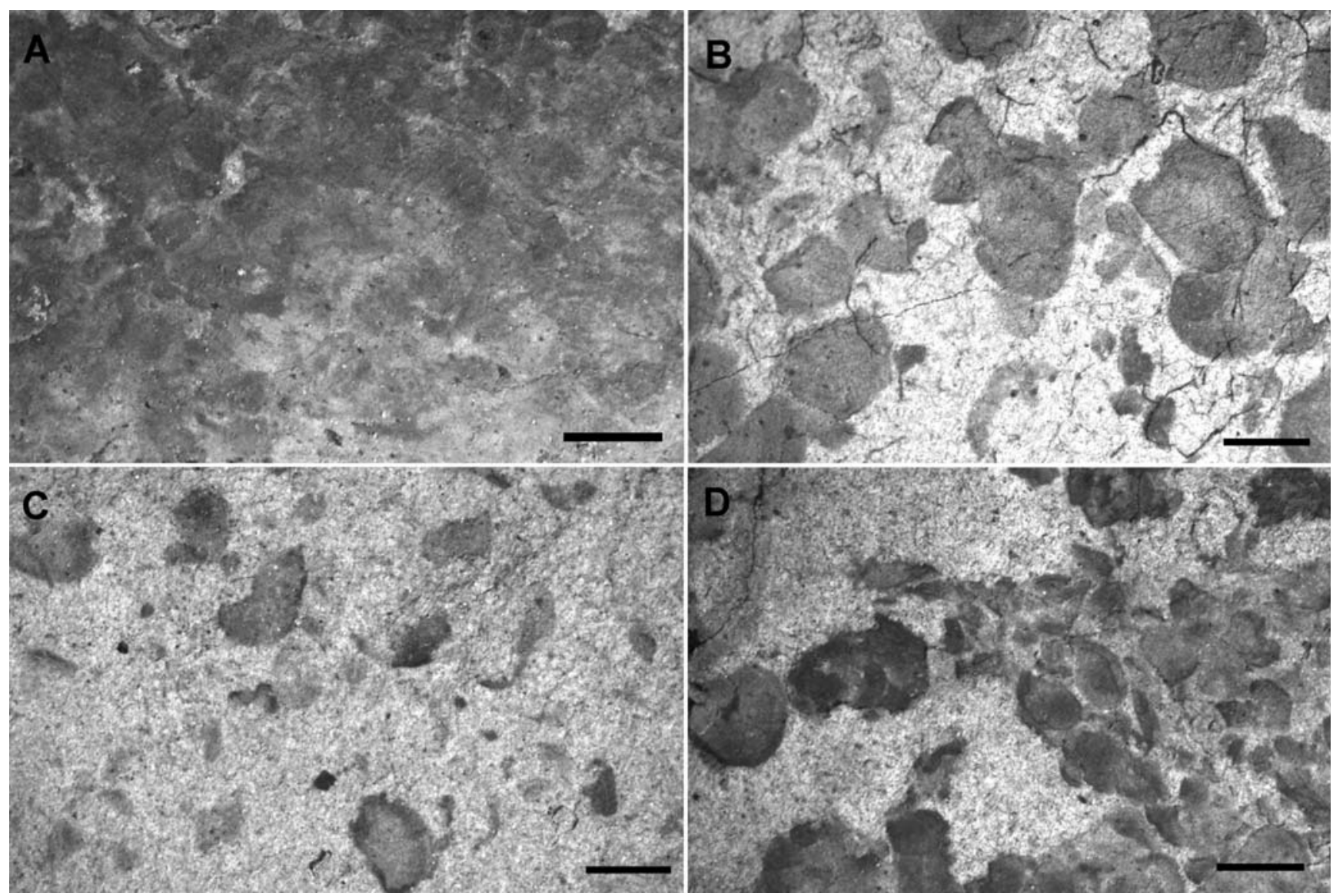

Figure 4 - Conchostraceans accumulations from Point A in plain view. Note the various degrees of carapace packing. A) Densely-packed, GP/1E-6198. B) Loosely-packed, GP/1E-6196. C) Dispersed, GP/1E-6204. D) Densely-packed assemblage (right) passing laterally to a loosely-packed assemblage (left), GP/1E-6200. Scale $2 \mathrm{~mm}$.

decrease in the level of the water body, with variations of oxygen content. The lack of tractive structures also points to a quiet water paleoenvironment and fossil decantation.

The association of fishes and arthropods may indicate that the depositional environment where they lived in was not temporary or seasonal water bodies.

\section{OTHER FOSSILS FROM TATUÍ FORMATION}

Besides the conchostraceans, other fossils from the Tatuí Formation at Ponte Nova Farm were also observed and reported.

Ichnoliths were the only evidence of organisms found in the facies 1 (Figs. 5C-D). It is located at the top of the facies, immediately below the facies 2 .

The ichnofossils consist of simple irregulars conical burrowings in fine sandstone, perpendicular to the bedding plane. On the rock surface, these structures bear irregular-shaped openings, varying from oval to elongate.

The ichnogenus Conichnus displays a conical shape (Fernandes et al. 2002), as the exemplar described in the present study (Figs. 5C-D), and an elongate opening when seen on the rock surface. Nonetheless, unlike the material from the present study, Conichnus has a chevron-like tube filling, which is diagnostic for this ichnogenus.

Cylindrichnus possesses a similar shape as the material from Tatuí Formation, but it is not found perpendicular to the bedding plane. Additionally, the outer wall of Cylindrichnus is made up of concentric layers (Fernandes et al. 2002).

The ichnogenus Ophiomorpha consists of simple burrowings, forming vertical nets (Fernandes et al. 2002), similar to the observed ichnofossils. Its wall, however, is made up of rounded to oval nodules, not seen in the material of the present study.

Skolithos also consists of vertical simple tubular excavations (Fernandes et al. 2002), but it differs from the ichnofossils from the Tatuí Formation for being quite regular on the plain view.

Among the ichnotaxa compared to the structure from Ponte Nova Farm, Arenicolites shares more similarities. It displays a simple to U-shaped structure 

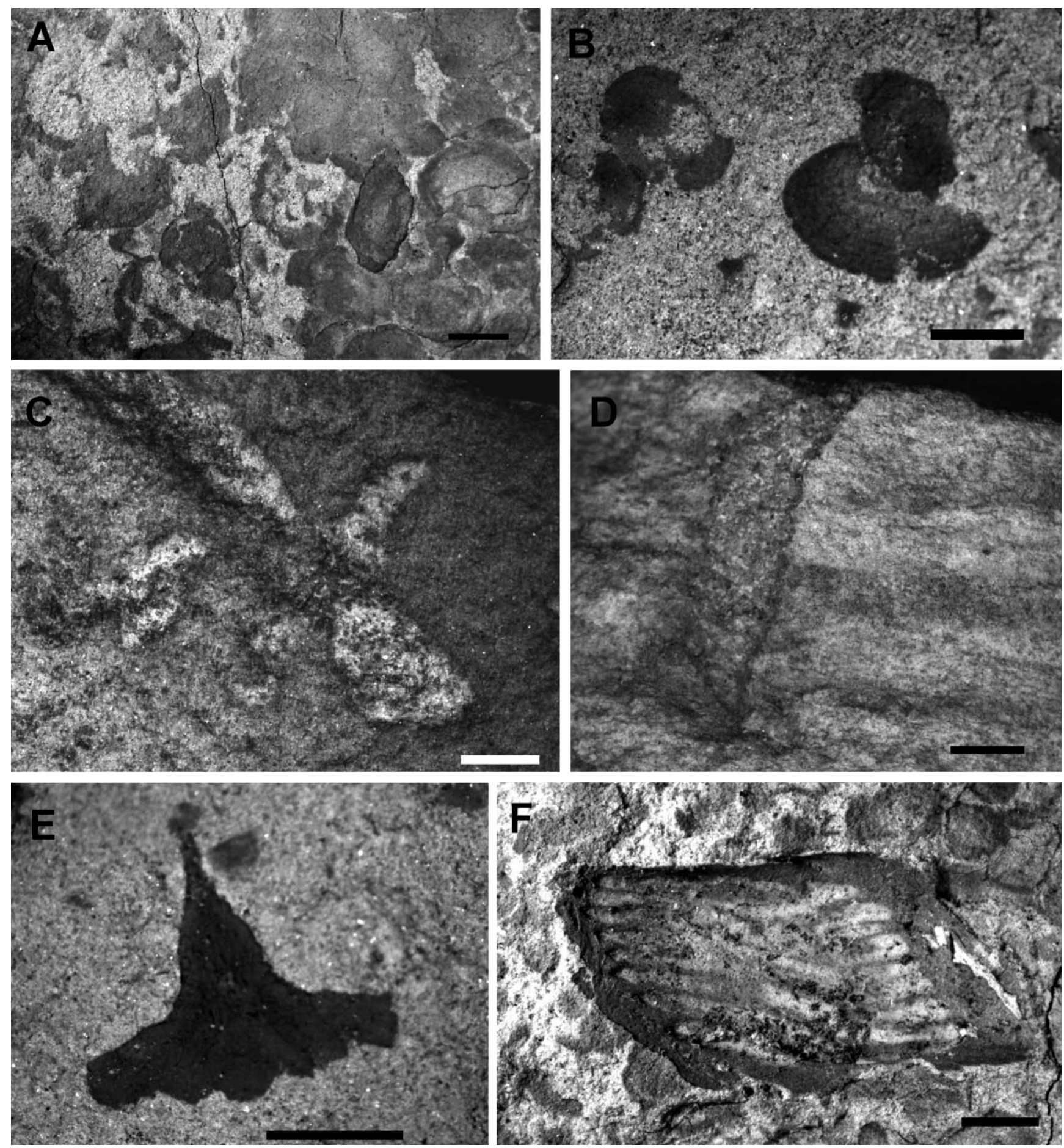

Figure 5 - Fossils found in the facies 2 of the Tatuí Formation. A) Conchostraceans seen in plain view. Note that the assemblage passes laterally from densely concentrated to sparsely concentrated, GP/1E-6201. B) Conchostraceans fragments showing superficial adornments, GP/1E-6202. C) Ichnofossil found in the facies 1 in plain view (C) and in section (D) GP/7E-352. E) Chitinous remain found in the facies 2, GP/1E-6205. F) Mould of Osteichthyes scale, GP/2E-6585. Scale corresponds to $2 \mathrm{~mm}$.

perpendicular to the bedding plane, occurring in laminated or stratified sandstones.

It is probable that the Tatuí ichnofossils have been developed under well-oxigenated, shallow waters.

Chitinous fragments ascribed to undetermined crustaceans were also observed to occur with the conchostraceans. They normally display pointed or crenulated flares in their posterior portion (Fig. 5E).

The occurrence of other types of crustaceans associated with conchostraceans in Tatuí Formation was already observed by Mezzalira \& Martins Neto (1992), who described two new isopod genera - Pseudopalaega 
and Protourda - in the unit. Up to now, no fossil fragment at Ponte Nova Farm could be related to these genera.

Vertebrate remains are found associated with the conchostraceans at Ponte Nova Farm. They consist on Osteichthyes remains and Palaeonisciformes scales (Fig. 5F).

The best preserved Palaeonisciformes scale consists of a paleoniscoid external mould of $10 \mathrm{~mm}$ long (Fig. 5F). The preserved details of the scale include its original rhombohedral outline, the whole imbrication surface and longitudinal ribs, which are compared to the fossils described by Chahud (2007) and Chahud \& Petri (2008b). The presence of these structures on this scale suggests that it has not suffered considerable may be none - transportation after its detachment from the animal. The large size of the structure suggests the great size of the Palaeonisformes, comparable in size to the Palaeonisformes from the overlying Taquaral Member (Chahud \& Petri 2008b).

Shapeless organic matter and possible coprolites were also observed, associated to the conchostraceans in the facies 2.

\section{PALEOENVIRONMENTS OF THE TATUÍ FORMATION DEPOSITS As far as the gathered} field data and fossils from the Ponte Nova outcrops, it is possible to infer their paleoenvironments.

The facies 1 , fine cross-bedded sandstone with subordinate plane-parallel strata, might be laid down by rather small coastal environment. The coarse deposits in outcrops of the facies 3 and the silty-sandy deposits of facies 2 bear the most evident information for paleoenvironments. During the period in which these two facies were deposited, the environment was characterized by a high energy river system. These rivers may have pushed southward the Rio Bonito and Palermo system of deposition.

This hypothesis is viable, as rivers controlling the coast line position are observable today. One example is the relation between the São Francisco River, and other parallel rivers, flowing directly to the Atlantic Ocean. With time, the river displace the coast line position and the flow causes the geographic coast line to migrate southward (Bacoccoli 1971, Gama Jr. 1976).

With the retreat of the larger water body, lakes and lagoons were formed at the coast line, with subsequent replacement from salty water to freshwater. This allowed the appearance of the conchostraceans. Such lakes could have seasonal switches in its water chemical composition, causing mass deaths, originating carapace accumulations. These layers were eroded by the river system from time to time, as observed at the points A and B.
In a second paleoenvironmental change, following freshwater deposits precede either storm or decantation deposits.

Storm deposits would be represented by fine sandstones with large cross beddings. These structures can be seen in outcrops in the region, as at Santa Maria Homestead (Chahud 2007, Chahud \& Petri 2010a), Passa Cinco River (Chahud 2007) or even in more remote locations, as the $\mathrm{Km} 150$ of the Sugar Road, between the localities of Piracicaba and Rio das Pedras (Chahud 2007). These deposits would be equivalent to the facies 4 at the top of Tatuí Formation.

Decantation deposits consist of siltites or very fine sandstones, and are in contact with the overlain Irati Formation. These deposits were noted in the region of Rio Claro city, near the Passa Cinco River (Chahud 2007) and in the Road SP-304 (km 151), between the cities of Piracicaba and Santa Bárbara D'Oeste (Assine et al. 2003). The deposits exhibit direct contact with the overlain Irati Formation in every situation.

Observations made in outcrops bearing storm deposits revealed that the paleoenvironment consisted in a large water body, suggested by the metric scale of the observed structures. Such water body would be related to the same agent that has originated the Palermo Formation deposits (Perinotto 1992).

This event is posterior to the event of the rivers, as observed at Point $\mathrm{C}$, where the coarse sandstone deposit of facies 3 underlies the cross-bedding fine sandstones in contact with the Irati Formation. This hypothesis reinforces the statement that the Ibicatu Facies and the sandstones of the base of Irati Formation do not belong to the same event (Assine et al. 2003, Chahud \& Petri 2010a).

In spite of the geological evidence that support the existence of a large water body, which resulted in the deposits of the facies 4 at the top of Tatuí Formation, there is no evidence for the salinity of this ancient environment, such as diagnostic fossils. However, acritarchs of the genus Michrystridium were reported in the contact between the Tatuí Formation and the overlie Irati Formation in southern São Paulo State and in the contact between the Palermo Formation (laterally equivalent to the Tatuí Formation in the southern Paraná Basin) and the Irati Formation in the south region of Brazil (Cazzulo-Kleipzig et al. 1989, Perinotto 1992, Araújo-Barberena 1993, Marasco et al. 1993). Such observations suggest a minimum salinity for the environment, but not necessarily enough for a marine setting, according to the cited authors. Therefore, the presence of Michrystridium may suggest a phase of salty water input into the water body. A similar situation refers to a "salty water stage" between two freshwater ones in the Late Pleistocene of the Baltic Sea. The 
"Yoldia Sea" phase represented a period of salinity due to the Baltic Sea confinement, with a span of 200 years (Brenner 2005). Like in the Palermo and Tatuí formations, only one acritarch genus was found in the "Yoldia Sea" deposits, together with freshwater algae (Brenner 2005). Likewise, Quaternary palinomorphs from the freshwater lake of Sapanca in Turkey would be remnants of a time when there was a connection to Black and Caspian seas. These microorganisms may have been adapted to freshwater environments with time (Leroy \& Albay 2010). As Brenner (2005), Leroy \& Albay (2010) observed that marine palynomorphs can occur in non-marine environments.

In both cases, the diversity of marine exemplars is quite low, as in the Tatuí Formation deposits. It suggests that the acritarchs would have originated in previous epochs and got restricted to places with some salinity or have adapted to the freshwater.

THE TAQUARAL MEMBER PALEONTOLOGY Fossils from facies 5 are more abundant and diversified than the other deposits. Agglutinating foraminiferans, poriferan spicules, acritarchs and ostracods were reported in the literature (Almeida \& Barbosa 1953, Cabral Jr. et al. 1988, Marasco et al. 1993), albeit never illustrated or formally described.

The silty shales of Taquaral Member at facies 6, in other localities have registered some undetermined acritarchs (Lages 2004), the algae Botryococcus - a typical freshwater genus - and the crustacean Clarkecaris.

At Ponte Nova Farm, only vertebrate fossils were observed, being constituted by Osteichthyes (Palaeonisciformes and Coelacanthiformes) and Chondrichthyes.

The observed Chondrichthyes occur only in facies 5 at Ponte Nova Farm, and are known from the Paraná Basin since the Early Permian, based on a cladodont tooth from the Budó Facies of Itararé Subgroup of Rio Grande do Sul State (Barcellos 1975). The commonest fossils from facies 5 at Ponte Nova Farm are Xenacanthiformes of the species Taquaralodus albuquerquei, which is also frequent in this facies in other localities (Chahud \& Petri 2008a, 2010b).

The teeth of Taquaralodus albuquerquei (Chahud \& Petri 2010b) possess a crown with two unequal lateral cusps and an axial one, this latter being very short or absent. These cusps are arranged approximately on the same labial edge plan at the base of the teeth (Fig. $6 \mathrm{~A}$ ), and are always inclined towards the lingual face. The largest cusp occupies about the half of the labial edge (Figs. 6A-B), and outstands perpendicularly to the base; the second cusp is arranged on the labial side of the tooth, and the axial cusp is set obliquely between the two other ones (Fig. 6A).

The unicuspid variety is related to ontogeny of the dental growth, being this type of teeth still juvenile in the mandible of the animal (Fig. 6B).

Petalodont fossils are also abundant in the facies 5 (Chahud 2007, Chahud et al. 2010), and are represented by the species Itapyrodus punctatus (Silva Santos 1990, Chahud \& Petri 2008a, Chahud et al. 2010). This taxon is recognized only by symphisian (Figs. 6C-D) and posterior-lateral teeth.

The species Taquaralodus albuquerquei and Itapyrodus punctatus are the only taxa found in the Pedra do Fogo Formation of the Parnaíba Basin (Silva Santos 1946, 1990, Chahud \& Petri 2008a). These species inhabited environments of variable salinity and characterize a connection between the Paraná and Parnaíba basins in the Early Permian (Chahud \& Petri 2008a).

Another Chondrichthyes at the sandy base of the Taquaral Member is represented by elasmobranch spines. These fossils consist of elongated spines possessing a tubercular surface and are attributed to Ctenacanthiformes, as Sphenacanthus sanpauloensis (Chahud et al. 2010).

The elasmobranch spine (Fig. 6E) found at Ponte Nova Farm, differs from other spines found elsewhere in the basal sandy facies of the Taquaral Member. The material is a fin spine, bearing seven large and smooth longitudinal ridges. The largest width between the ridges is $2.7 \mathrm{~mm}$ seen on on the second lateral frontal. The space between the ridges is $0.6 \mathrm{~mm}$ and it is constant through the entire spine length. Each ridge shows three bifurcations located at different points of the structures. One of these bifurcations occurs in the central region of one of the sideways.

The spine clearly displays a slight convexity of the anterior face and a concavity at the posterior part. No lateral denticles or tubercular surface were noted on the ridges. The spine does not possess articulation zone nor preserved apex.

Based on the wide smooth ridges of the studied specimens, it is possible to state that they doesn't belong to known Paleozoic elasmobranches genera as Bythiacanthus, Eunemacanthus, Wodnika and Ctenacanthus (Maisey 1981, 1982, 1984). The genus Sphenacanthus have some representatives which do not bear tubercular surfaces on the fin spine ridges, as Sphenacanthus hybodoides (Maisey 1982). This species, however, possesses thinner ridges, when compared to those of the taxon from the Ponte Nova Farm. The genus Hybodus and Acondylacanthus, common in the Permian, also possess smooth ridges (Itano et al. 2003), but their fin spines are oval in cross section, differing from the triangular shape of the 
A

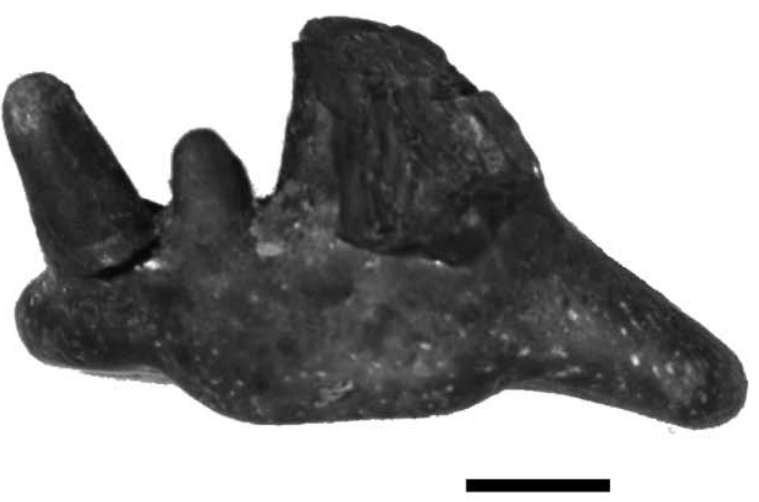

C

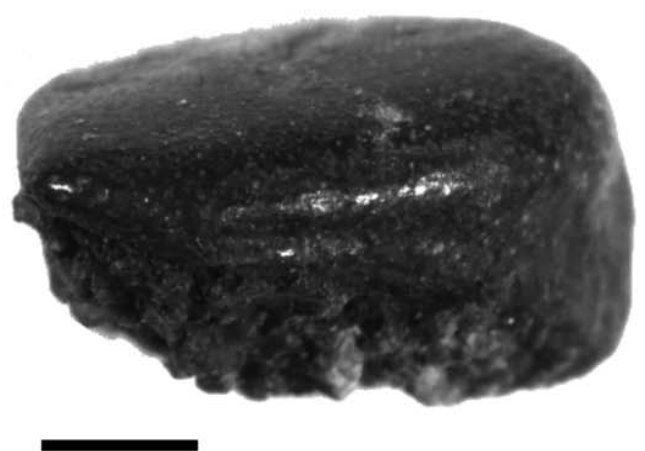

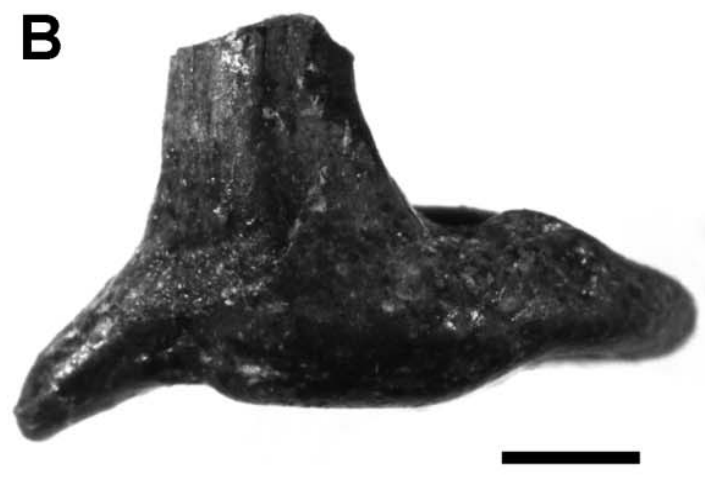

D

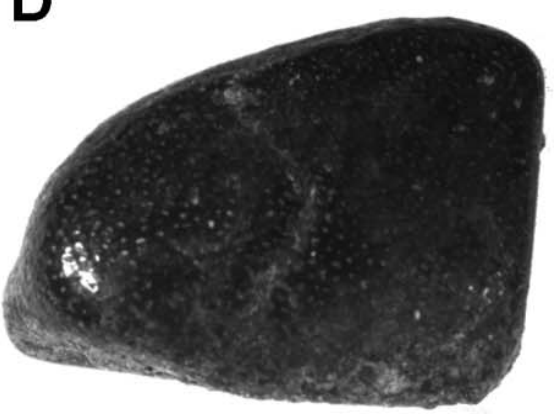

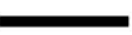

$\mathbf{E}$

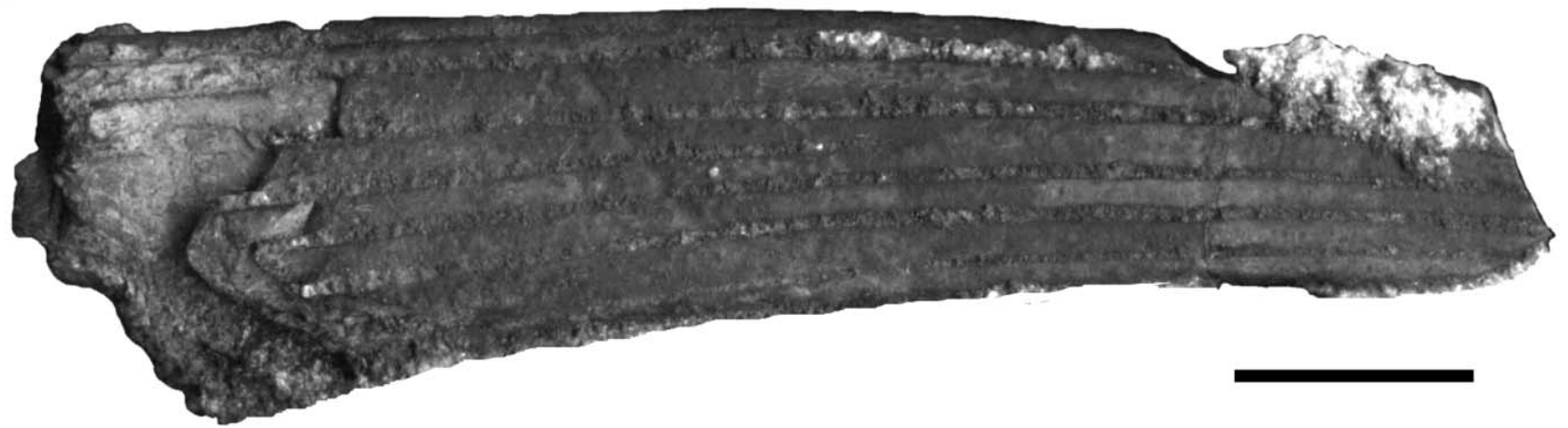

Figure 6 - Chondrichthyes found at facies 5. A-B) Teeth of Taquaralodus albuquerquei (A) GP/2E-6580; B) GP/2E-6581; C-D) Lateral-posterior tooth of Itapyrodus punctatus, GP/2E-6589, C) Lateral view. D) Occlusal view. E) Elasmobranch spine, GP/2E-6579. Scales: $2 \mathrm{~mm}$.

studied material. Amelacanthus is the genus that shares more similar charcteristics with the Ponte Nova Farm fossil. Its fin spine has wide and smooth ridges, with narrow intercostal notches and primary bifurcation. It also shows a slight curvature, and a triangular shape in transversal section, with a flattened posterior wall (Maisey 1981, 1982).

Bony fragments consist on the commonest fossils of the Taquaral Member, and belong to Actinopterygii (Figs. 7A and B) and Sarcopterygii (Fig. 7C) (Chahud \& Petri 2010a).
TAPHONOMIC AND PALEOENVIRONMENTAL CONSIDERATIONS ON THE TAQUARAL MEMBER The fossils of the sandy facies 5 of the Taquaral Member are dispersed and punctually concentrated. Both fossils and inorganic clasts are spread on the rock. The punctually concentrations are weakly packed, and the bioclasts either touch each other or lie very close, occupying a maximum area of $25 \mathrm{~cm}^{2}$.

In plain view, the fossils do not show any preferred orientation. In section, the material lies concordant to the bedding plane, even in the portions 

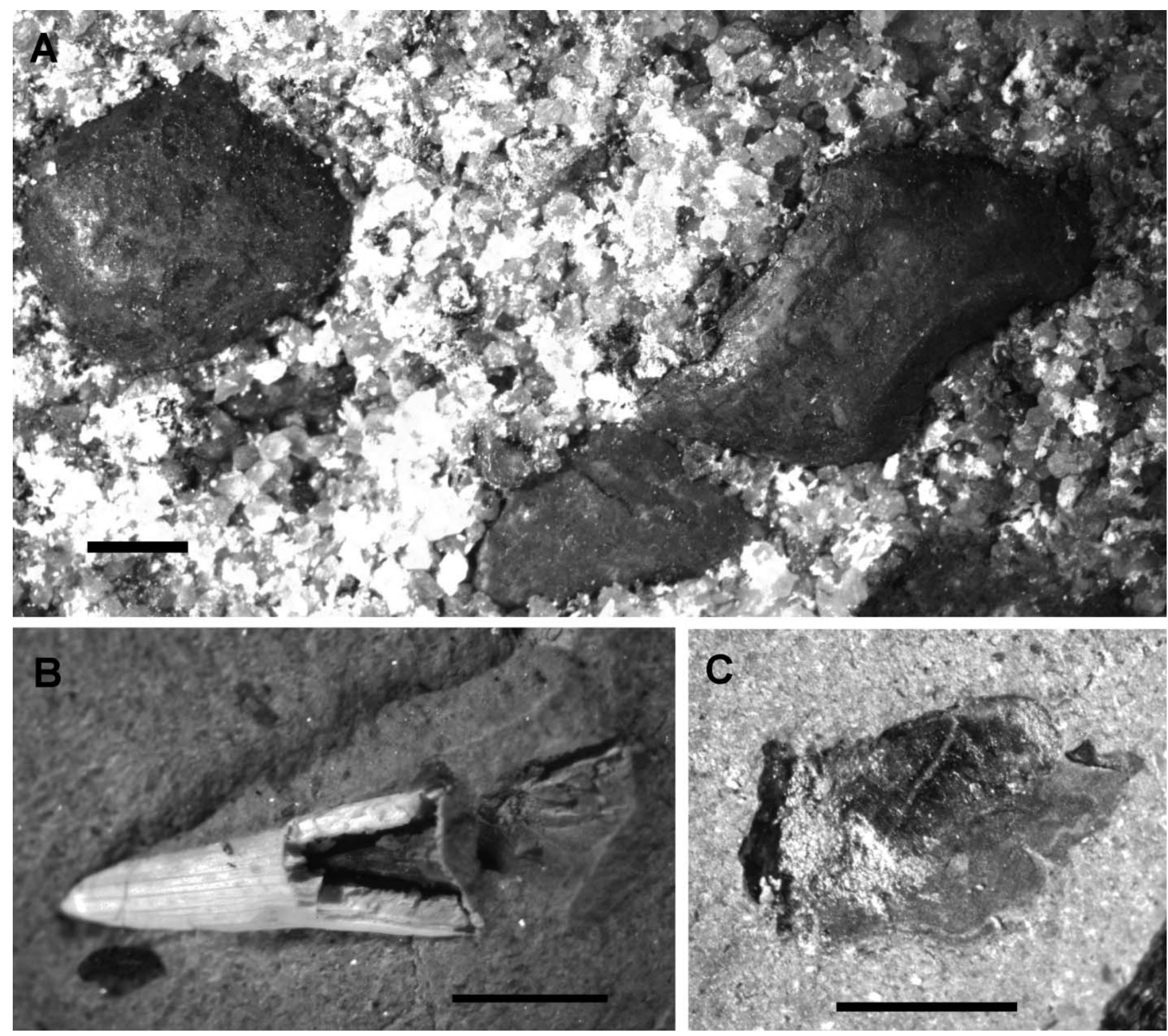

Figure 7 - Bony fish fossils from the facies 5 and 6 at Ponte Nova Farm. A) Abraded scales from the facies 5, GP/2E-6587. Scale: $2 \mathrm{~mm}$. B) Palaeonisciformes tooth from the facies 6, GP/2E-6586. Scale: $1 \mathrm{~mm}$. C) Coelacanthiformes fragmented scale from the facies 6, GP/2E-6588. Scale: $1 \mathrm{~mm}$.

where the rock is irregular cross-bedded and with wavy structures.

The punctuated aggregates are composed of larger bioclasts. Most of the fossils exhibit abraded surfaces in subordinate quantity, with no signals of reworking.

No articulated or complete specimen was found, the largest exemplars are found at the basal portion of the layer, as well as the largest inorganic clasts. The Ctenacanthiformes spine - the largest fossil of this facies was found at the contact with the facies 4 of the Tatuí Formation. This basal facies of the Taquaral Member is the result in the deposition in an energetic environment. This interpretation is based on the following observations: low selection of fossils and sedimentary material, bioclast fragmentation, absence of articulated fossils, scales and teeth exhibiting abraded surfaces, and the chaotic disposition of the fossils in plain view.

Most of the invertebrate and vertebrate fossils from the facies 6 - shales of Taquaral Member - consist of millimetric to centimetric fragments preserved as flattened and compressed structures, rare and dispersed in the deposit. Most of the remnants attributed to vertebrates is composed of bony fish scales and teeth, with no evidence of transport.

No fossil from the Taquaral Member is diagnostic of a marine environment. Fossils which were mentioned 
from the Palermo and Tatuí formations, as acritarchs, lingulids and possible agglutinating foraminiferans (Fúlfaro et al. 1984, Holz et al. 1998) are known to occur in paleoenvironments of variable salinity (Cabral Jr. et al. 1988, Lages 2004). Based on this, it is possible that some organisms survived to the environmental shifts through the top of the Taquaral Member; these organisms would become restricted to the specific conditions of the basin, in a parallel with the inland seas of Caspian and Aral (Zenkevich 1957).

CONCLUSIONS The Ponte Nova Farm is composed of six distinct facies, four of which from the Tatui Formation, and two from the Taquaral Member, Irati Formation.

The facies 1 basal cross-bedding well-sorted fine sandstone from the points $\mathrm{A}$ and $\mathrm{B}$ does not give substantial information on the paleoenvironment which generated them. The ichnofossil described here does not provide any additional information.

Facies 2 and 3 characterize the freshwater domain in the Tatuí Formation. The conglomeratic deposits from the facies 3 , interbedded with the facies 2 , exhibit a predominance of rounded clasts and matrix composed of coarse sand and granules (1-3 mm). The diastems of the points A and B suggest a fluvial system.

Conchostraceans, typical freshwater animals, are found in the facies 2 . Their size variation, preservation, abundance, and density must be considered for the formulation of the paleoenvironment hypothesis, as discussed below.
The facies 3 was probably generated under a fluvial channel subenvironment while facies 2 was generated on a flood plain. As reported above, the facies 2 lies either under the facies 3 or above it, through a diastem. The same is applied to the contact between facies 1 and 3, attesting the different position of the channel in relation to the other subenvironments.

The facies 4, at the top of the Tatuí Formation, in contact with the overlain sandy base of the Taquaral Member (facies 5), a phase posterior to the freshwater stage, and would be related to the sandy deposits sometimes storm-generated - found elsewhere (Chahud 2007, Chahud \& Petri 2010a). During this stage, it is possible to infer the presence of a large water body, yet no conclusions on the salinity levels can be taken.

Facies 5 and 6, typical of the Taquaral Member in the region (Hachiro 1997, Assine et al. 2003, Chahud \& Petri 2010a, Chahud et al. 2010) are identical to those observed elsewhere. Their presence testifies a subsidence of the basin, generating the Taquaral Member deposits. The maximum flood may be responsible for a brief interbasinal connection during the Early Permian, as suggested by the presence of the taxa Taquaralodus albuquerquei and Itapyrodus punctatus in both Paraná and Parnaíba basins.

Acknowledgments This research was supported by FAPESP (2007/51071-4). We acknowledge Andréia Cristiane Teodoro and Silas Gubittoso for their important help in the field work. And thanks to Mr. Bartman for letting us get in his farm (Fazenda Ponte Nova).

\section{References}

Almeida F.F.M. \& Barbosa O. 1953. Geologia das quadrículas de Piracicaba e Rio Claro, Estado de São Paulo. Rio de Janeiro, DNPM/DGM, Boletim 143, 96 p.

Araújo-Barberena D.C. 1993. Uma interpretação sobre o conhecimento paleoecológico e bioestratigráfico da Formação Irati. In: UNESP, Simpósio de Cronoestratigrafia da Bacia do Paraná, 1, Boletim de Resumos, p. 64-70.

Assine M.L., Zacharias A.A., Perinotto J.A.J. 2003. Paleocorrentes, paleogeografia e sequências deposicionais da Formação Tatuí, centro-leste do Estado de São Paulo. Revista Brasileira de Geociências, 33(1):33-40.

Bacoccoli G. 1971. Os deltas holocênicos brasileiros: Uma tentativa de classificação. Boletim Técnico da Petrobras, 74(1/2):5-38.

Barcellos M.T. 1975. Estudo de escamas e dentes de peixes da Fácies Budó, Subgrupo Itararé, RGS. Boletim Paranaense de Geociências, 32:3-65.

Bernardes de Oliveira M.E.C. 1977. Tafoflora eogondvânica da camada Irapuá, Formação Rio Bonito (Grupo Tubarão), SC. Tese de Doutorado, Instituto de Geociências, Universidade de São Paulo, São Paulo, 301 p.

Brenner W.W. 2005. Holocene environmental history of the Gotland Basin (Baltic Sea) - a micropalaeontological model. Palaeogeography, Palaeoclimatology, Palaeoecology, 220:227-241.

Brito I.M., Carvalho I.S., Vicalvi M.A., Carvalho M.G.P. 2000. Artrópodes. In: Carvalho I.S. (ed.) Paleontologia. Rio de Janeiro, Editora Interciência, p. 423-451.

Cabral Jr. M., Campanha V.A., Motta J.F.M., Saad A.R. 1988. Contribuição à estratigrafia e paleogeografia da interface Itararé e Tatuí (P) e considerações sobre sua potencialidade para carvão no Estado de São Paulo. In: SBG, Congresso Brasileiro de Geologia, 35, Anais, p. 879-892.

Cazzulo-Klepzig M., Piccoli A.E.M., Marques-Toigo M. 1989. Reconhecimento de um marco estratigráfico com significado paleoecológico no Permiano da Bacia do Paraná (Grupos Guatá e Passa Dois). In: SBG, Congresso 
Brasileiro de Paleontologia, 11, Anais, p. 971-982.

Chahud A. 2007. Paleontologia de Vertebrados da Transição entre os grupos Tubarão e Passa Dois no Centro-Leste do Estado de São Paulo. Dissertação de Mestrado, Instituto de Geociências, Universidade de São Paulo, São Paulo, $172 \mathrm{p}$.

Chahud A., Fairchild T.R., Petri S. 2010. Chondrichthyans from the base of the Irati Formation (Early Permian, Paraná Basin), São Paulo Brazil. Gondwana Research, 18:528-537.

Chahud A. \& Petri S. 2008a. Chondrichthyes no Membro Taquaral, base da Formação Itati, no centro-leste do Estado de São Paulo, Brasil. Revista de Geologia, 21:169-179.

Chahud A. \& Petri S. 2008b. Registro de Paleoniscóides na base do Membro Taquaral, Formação Irati, Permiano da Bacia do Paraná. Revista do Instituto Geológico, 29:33-40.

Chahud A. \& Petri S. 2010a. Anfíbio e Paleonisciformes da Porção Basal do Membro Taquaral, Formação Irati (Permiano), Estado de São Paulo, Brasil. Geologia USP. Série Científica, 10(1):29-37.

Chahud A. \& Petri S. 2010b. O tubarão Taquaralodus albuquerquei (Silva Santos, 1946) do Membro Taquaral (Permiano, Formação Irati) no Estado de São Paulo. Acta Biológica Paranaense, 39(1-2):1-17.

Chen P.J. \& Hudson J.D. 1991. The Conchostracan fauna of the Great Estuarine Group, Middle Jurassic, Scotland. Palaeontology, 15(3):515-545.

Fernandes A.C.S., Borghi L., Carvalho I.S., Abreu C.J. 2002. Guia dos Icnofósseis de Invertebrados do Brasil. Rio de Janeiro, Editora Interciência, 260 p.

Ferreira de Oliveira L.G. 2007. Conchostráceos permianos da Bacia do Paraná: taxonomia, evolução, bioestratigrafia e paleobiogeografia. Tese de Doutorado, Instituto de Geociências e Ciências Exatas, Universidade Estadual Paulista, Rio Claro, 241 p.

Fúlfaro V.J., Stevaux J.C., Souza-Filho E.E., Barcelos J.H. 1984. A Formação Tatuí (P) no Estado de São Paulo. In: SBG, Congresso Brasileiro de Geologia, 33, Anais, p. 711-723.

Gama Jr. E.G. 1976. Análise de tendência de espessuras do Membro Marituba da Formação Piaçabuçu da Bacia de Sergipe-Alagoas. In: SBG, Congresso Brasileiro de Geologia, 29, Anais, p. 234-239.

Hachiro J. 1991. Litotipos, associaçoes faciológicas e sistemas deposicionais da Formação Irati no estado de São Paulo. Dissertação de Mestrado, Instituto de Geociências, Universidade de São Paulo, São Paulo, 175 p.

Hachiro J. 1997. O Subgrupo Irati (Neopermiano) da Bacia do Paraná. Tese de Doutorado, Instituto de Geociências, Universidade de São Paulo, São Paulo, 196 p.

Holz M., Zwetsch G., Simões M.G., Carlucci R. 1998. Tafonomia dos invertebrados na Formação Palermo (Kunguriano) da Bacia do Paraná no Rio Grande do Sul: Lingulídeos desarticulados em fácies de tempestitos. In: SBG, Congresso Brasileiro de Geologia, 40, Boletim de Resumos, p. 453.

Itano W.M., Houk K.J., Lockley M.J. 2003. Ctenacanthus and other chondrichthyan spines and denticles from the Minturn Formation (Pennsylvanian) of Colorado. Journal of Paleontology, 77:524-535.

Kobayashi T. 1954. Fossil Estherians and allied fossils. Journal of the Faculty of Science, 9(1):1-192.

Lages L.C. 2004. A Formação Irati (Grupo Passa Dois, Permiano, Bacia do Paraná) no furo de sondagem FP-01PR (Sapopema, PR). Dissertação de Mestrado, Instituto de Geociências e Ciências Exatas, Universidade Estadual Paulista, Rio Claro, 117 p.

Leroy S.A.G. \& Albay M. 2010. Palynomorphs of brackish and marine species in cores from the freshwater Lake Sapanca, NW Turkey. Palynomorphs of brackish and marine species in cores from the freshwater Lake Sapanca, NW Turkey. Review of Palaeobotany and Palynology, 160(3-4):181-188.

Maisey J.G. 1981. Studies on the Paleozoic selachian genus Ctenacanthus Agassiz. No. 1. Historical review and revised diagnosis of Ctenacanthus, with a list of referred taxa. American Museum Novitates, 2718:1-22.

Maisey J.G. 1982. Studies on the Paleozoic selachian genus Ctenacanthus Agassiz. No. 2. Bythiacanthus St. John and Worthen, Amelacanthus, New Genus, Eunemacanthus St. John and Worthen, Sphenacanthus Agassiz, and Wodnika Münster. American Museum Novitates, 2722:1-24.

Maisey J.G. 1984. Studies on the Paleozoic selachian genus Ctenacanthus Agassiz. No. 3. Nominal species referred to Ctenacanthus. American Museum Novitates, 2774:1-20.

Marasco S.A., Souza P.A., Pires F.A. 1993. Ocorrência de paleomicroplâncton marinho (Acritarcha) associado a ictiofósseis na base do Membro Taquaral, Formação Iratí (Permiano Superior da bacia do Paraná), região de Itapetininga, Estado de São Paulo. In: SBP, Congresso Brasileiro de Paleontologia, 13, Simpósio Paleontológico do Cone Sul, 1, Resumos, p. 60.

Martin J.W. \& Cash-Clark C.E. 1995. The external morphology of the onychopod "cladoceran" genus Bythotrephes (Crustacea, Branchiopoda, Onychopoda, Cercopagididae), with notes on the morphology and phylogeny of the order Onychopoda. Zoologica Scripta, 24:61-90.

Mezzalira S. 1952. Clarkecaris, novo gênero de crustáceo Syncarida do Permiano. Boletim da Sociedade Brasileira de Geologia, 1(1):46-52.

Mezzalira S. \& Martins-Neto R.G. 1992. Novos crustáceos paleozóicos do Estado de São Paulo com descrição de novos taxa. Acta Geológica Leopoldensia, 15(36):49-66.

Milani E.J., Melo J.H.G., Souza P.A., Fernandes L.A., Franca A.B. 2007. Bacia do Paraná. Boletim de Geociências da Petrobrás, 15:265-287.

Olesen J. 1998. A phylogenetic analysis of the Conchostraca and Cladocera (Crustacea, Branchiopoda, Diplostraca). Zoological Journal Linnean Society, 122:491-536.

Olesen J., Martin J.W., Roessler E.W. 1996. External morphology of the male of Cyclestheria hislopi (Baird, 1859) (Crustacea, Branchiopoda, Spinicaudata), with a comparison of male claspers among the Cochostraca and Cladocera and its bearing on phylogeny of the "bivaled" Branchiopoda. Zoologica Scripta, 25:291-316.

Perinotto J.A. 1992. Análise estratigráfica da Formação Palermo (P) na Bacia do Paraná, Brasil. Tese de 
Paleontology and depositional environments of the Tatuí and Irati formations (Permian) in the Ponte Nova Farm, Ipeúna, state of São Paulo

Doutorado, Instituto de Geociências e Ciências Exatas, Universidade Estadual Paulista, Rio Claro, 115 p.

Riccomini C., Sant’anna L.G., Coimbra A.M. 1997. Sílica microcristalina (Trípoli) em rochas sedimentares permianas do flanco leste da bacia do Paraná, Estado de São Paulo, Brasil. Revista Brasileira de Geociências, 27(4):395-402.

Saad A.R. 1977. Projeto: Estratigrafia do Grupo Tubarão no Estado do Paraná. Curitiba, CNPq, Relatório final, 11 p.

Schminke H.K. 1981. Adaptation of Bathynellacea (Crustacea, Syncarida) to life in the interstitial (“Zoea Theory"). Internationale Revue gesamten Hydrobiologie, 66:575-637.

Silva Santos R. 1946. Duas novas formas de elasmobranquios do Paleozóico do Meio Norte do Brasil. Anais da Academia Brasileira de Ciências, 18(4):281-285.

Silva Santos R. 1990. Paleoictiofáunula da Formação
Pedra do Fogo, Nordeste do Brasil: Holocephali Petalodontidae. Anais da Academia Brasileira de Ciências, 62(4):347-355.

Soares P.C. 1972. O limite glacial/pós-glacial do Grupo Tubarão no Estado de São Paulo. Anais da Academia Brasileira de Ciências, 44(Suplemento)333-342.

Stevaux J.C., Souza-Filho E.E., Fúlfaro V.J. 1986. Trato deposicional da Formação Tatuí (P) na área aflorante do NE da Bacia do Paraná, Estado de São Paulo. In: SBG, Congresso Brasileiro de Geologia, 34, Anais, p. 219-229. Zenkevitch L. 1957. Caspian and Aral Seas. In: Hedgpeth J.W. (ed.) Treatise on marine ecology and paleoecology. New York, Geological Society of America, p. 891-916.

Manuscrito ID 21492

Submetido em 09 de maio de 2011 Aceito em 07 de fevereiro de 2012 